\title{
Anti-trachoma League
}

In the Revue Générale d'Ophtalmologie for November, 1922, will be found an interesting résumé of the proceedings of the trachoma meeting of the French Colonial Congress of Public Health, held at Marseilles on September 15 last. After a number of oculists had dealt with various points in connection with trachoma-the chief of which were the question of compulsory notification and the formation of an Anti-trachoma League-Morax outlined the functions of the League. These may be summarised as follows:-(1) The collection of statistics, (2) propaganda work, (3) subvention of research, (4) organization of anti-trachomatous hygiene and therapeutics in. infected regions, (5) social and financial support, and (6) the establishment of hospitals, dispensaries and laboratories. Professor Truc of Montpellier closed the discussion by putting to the meeting the following resolution:-

"The Colonial Congress of Public Health, considering that granular ophthalmia constitutes a formidable scourge in our colonies and in certain important centres of the metropolis, is of opinion (1 that the fight against trachoma should be organized in a more methodical and active manner, (2) that an anti-trachoma league should be founded charged with the duty of studying the regulations and measures to be taken, and of giving support to all efforts in the direction of studying and combating this contagious ophthalmia."

The resolution was unanimously adopted by the meeting.

\section{COUNCIL OF BRITISH OPHTHALMOLOGISTS ANNUAL REPORT}

THE Council of British Ophthalmologists presents its report for the Session 1922-23.

At the first meeting of the Session the following officers were elected :-President, Mr. J. B. Lawford; Vice-Presidents, Sir George Berry and Mr. E. Treacher Collins; Hon. Treasurer, Mr. J. H. Fisher; Hon. Secretary, Mr. M. S. Mayou.

The following members were elected to serve on the Executive Committee :-

Messrs. Collins, Fisher, Paton, and Sir John H. Parsons, with the President and Secretary ex-officiis.

The Council has revised and published the report on the question of Sight-testing Opticians.

A Committee is still engaged on the Standardization of Test Types.

At the instigation of the Royal Society of Medicine, a new 
Committee has been appointed to deal with the standards of vision for scholars and teachers in Council Schools.

During the course of the year several questions have been referred to the Council for its opinion and advice. Amongst these may be mentioned that of lectures to candidates for the examinations of the British Optical Association and Spectacle Makers Co., by the Universities of Glasgow and Liverpool; also proposals concerning sight-testing by opticians under the National Insurance Act.

Another important question which the Council has had under consideration is the establishment of an International Year Book of Ophthalmology in English, proposed by Ophthalmologists in America.

The expenses of the Council have been defrayed as in previous years by its members.

The Council has to thank the Council of the Royal Society of Medicine for the use of a room for its meetings.

\section{ABSTRACTS}

\section{I.-LATE RESULTS OF SCLERECTO-IRIDECTOMY}

Lagrange and Baron.-Remote results of sclerecto-iridectomy in the treatment of chronic glaucoma. (Résultats éloignés de la sclérecto-iridectomie dans le traitement du glaucome chronique.) Arch. d'Ophtal., January, 1923.

The eminence of the senior author and the precision with which he and his assistant have collated the results of 10 years' work give exceptional value to this article. It covers 40 pages, presents five principal headings, and abounds in figures; the following is merely a summary.

1. Precision in terminology. Lagrange's well-known operation comprises excision of tissue from sclera and from iris, and the author's name for it is correct. The term " irido-sclerectomie," substituted by certain writers, is faulty for it does not indicate the treatment of the iris; true, it is shorter by one syllable and a little easier to say, but precision should not be sacrificed to brevity or euphony.

2. What are to be taken as remote results? In general surgery cicatrices change long after the lips of the wound are joined, and the same is true of incisions in the eye. In chronic glaucoma success depends on lasting fistulization of the eye, and at least one year should pass before the result is reported. All cases included in these statistics were re-examined at least one year after the 